medRxiv preprint doi: https://doi.org/10.1101/2021.05.27.21257938; this version posted May 28, 2021. The copyright holder for this preprint (which was not certified by peer review) is the author/funder, who has granted medRxiv a license to display the preprint in perpetuity.

It is made available under a CC-BY 4.0 International license.

\title{
1 NON-PHARMACEUTICAL INTERVENTIONS AND THE EMERGENCE OF PATHOGEN VARIANTS
}

2

3 Ben Ashby ${ }^{1 *}$ and Robin N. Thompson ${ }^{2,3}$

4

5 1. Department of Mathematical Sciences, University of Bath, Bath, UK

6 2. Mathematics Institute, University of Warwick, Coventry, UK

7

3. Zeeman Institute for Systems Biology and Infectious Disease Epidemiology Research,

8 University of Warwick, Coventry, UK

9

$10 *$ Corresponding author: benashbyevo@gmail.com

11

12 Keywords: pathogen evolution, transmissibility, immune escape, cross-immunity, social

13 distancing, lockdowns

NOTE: This preprint reports new research that has not been certified by peer review and should not be used to guide clinical practice. 
medRxiv preprint doi: https://doi.org/10.1101/2021.05.27.21257938; this version posted May 28, 2021. The copyright holder for this preprint (which was not certified by peer review) is the author/funder, who has granted medRxiv a license to display the preprint in perpetuity.

It is made available under a CC-BY 4.0 International license .

\section{AbStRACT}

15 Non-pharmaceutical interventions (NPIs), such as social distancing and contact tracing, have

16 been widely implemented during the COVID-19 pandemic. In addition to playing an

17 important role in suppressing transmission, NPIs influence pathogen evolution by mediating

18 mutation supply and altering the strength of selection for novel variants. However, it is

19 unclear how NPIs might affect the emergence of novel variants of concern that are able to

20 escape pre-existing immunity (partially or fully), are more transmissible, or cause greater

21 mortality. Here, we analyse a stochastic two-strain epidemiological model to determine how

22 the strength of NPIs affects the emergence of variants with similar or contrasting life-history

23 characteristics to the wildtype. We show that, while stronger and timelier NPIs generally

24 reduce the likelihood of variant emergence, it is possible for more transmissible variants

25 with high cross immunity to have a greater probability of emerging at intermediate levels of

26 NPIs. However, since one cannot predict the characteristics of a variant, the best strategy to

27 prevent emergence is likely to be implementation of strong, timely NPIs. 
medRxiv preprint doi: https://doi.org/10.1101/2021.05.27.21257938; this version posted May 28, 2021. The copyright holder for this preprint (which was not certified by peer review) is the author/funder, who has granted medRxiv a license to display the preprint in perpetuity.

It is made available under a CC-BY 4.0 International license .

\section{AUTHOR SUMMARY}

29 During the COVID-19 pandemic, a wide range of non-pharmaceutical interventions,

30 including mask wearing, quarantine, isolation, and lockdowns, have been used by

31 governments around the world to suppress virus transmission. Although considerable

32 efforts have been made to understand how such interventions affect transmission, much

33 less attention has been paid to their effects on pathogen evolution. While vaccines are well-

34 known to affect virus evolution, non-pharmaceutical interventions also influence mutation

35 supply and the strength of selection, and hence play a key role in the emergence of novel

36 variants. Here, we use a relatively simple mathematical model to explore how non-

37 pharmaceutical interventions during an epidemic affect the emergence of a novel variant of

38 a pathogen. We show that in general, it is important to implement effective transmission-

39 reducing public health measures in a timely manner to prevent the emergence of novel

40 variants, which may be more transmissible, more deadly, or able to escape immunity. 
medRxiv preprint doi: https://doi.org/10.1101/2021.05.27.21257938; this version posted May 28, 2021. The copyright holder for this preprint (which was not certified by peer review) is the author/funder, who has granted medRxiv a license to display the preprint in perpetuity.

It is made available under a CC-BY 4.0 International license .

\section{INTRODUCTION}

42 Understanding the impact of interventions for infectious disease control on pathogen

43 evolution is a major challenge at the interface of public health and evolutionary biology [1-

44 3]. During the COVID-19 pandemic, a wide range of non-pharmaceutical interventions (NPIs)

45 have been implemented across the world, including social distancing, improved hygiene

46 practices, lockdowns, quarantining exposed or isolating infected individuals, and contact

47 tracing. Such measures have been credited with reducing cases and bringing epidemics

48 under control, both prior to and in conjunction with vaccine rollouts [4-7]. Recently, there

49 has been renewed interest in the effects of vaccination programmes on pathogen evolution

50 and subsequent transmission. This includes the potential for more transmissible or more

51 virulent variants, or those that are able to escape naturally- or vaccine-induced immunity

52 [8-13]. However, while the impact of vaccination on SARS-CoV-2 evolution has been the

53 subject of significant recent interest, there has been relatively little attention directed at the

54 effects of NPIs on the emergence on novel variants of concern $[1,14]$.

56 The emergence of a novel variant occurs in two stages. First, the variant must be generated

57 through mutation or recombination ("appearance"). Mutation supply governs the

appearance of a new variant and depends on the rate at which the pathogen replicates in

59 the host population (determined by the number of infected hosts [10]), the mutation rate, and the number of mutations required to generate the variant. By reducing opportunities

61 for transmission, NPIs effectively lower the rate at which the pathogen replicates, and hence lower the mutation supply. NPIs should therefore always make the appearance of novel variants less likely. 
medRxiv preprint doi: https://doi.org/10.1101/2021.05.27.21257938; this version posted May 28, 2021. The copyright holder for this preprint (which was not certified by peer review) is the author/funder, who has granted medRxiv a license to display the preprint in perpetuity.

It is made available under a CC-BY 4.0 International license .

65 If a variant does appear, then the second stage for emergence requires sustained

66 transmission between hosts ("establishment" - Fig. 1a). It should be noted that many

67 variants are likely to appear that have little or no impact on pathogen transmission or

68 virulence [1,15]. Variants may appear but remain undetected as they are unable to become

69 established due to selection (if the variant is less fit than the wildtype) [16] or stochastic

70 extinction (if by chance the variant dies out before it can infect many hosts) [17-19]. NPIs

71 are likely to have more complex effects on the establishment phase as they mediate both

72 the strength of selection and the likelihood of stochastic extinction. For example, stronger

73 NPIs will slow the rate at which a variant can spread and will increase the likelihood of

74 stochastic extinction, but will also change how immunity accumulates in the host

75 population. Increased immunity to the wildtype virus could strengthen selection for the

76 variant.

Here, we analyse a stochastic model of pathogen evolution to explore the effects of NPIs on

the emergence of novel variants. We show how the strength and timing of NPIs, along with

80 the life-history characteristics of the variant, affect its emergence and impact on the host population.

MethodS

84 To explore the key factors underlying the emergence of novel variants in a simple setting,

85 we model infectious disease dynamics in a well-mixed, homogeneous host population over

86 a relatively short period, ignoring host births and natural mortality for simplicity (see Fig. 1b

87 for model structure). We restrict our model to two strains, a wildtype ( $w)$ and a variant ( $v)$, 
medRxiv preprint doi: https://doi.org/10.1101/2021.05.27.21257938; this version posted May 28, 2021. The copyright holder for this preprint (which was not certified by peer review) is the author/funder, who has granted medRxiv a license to display the preprint in perpetuity.

It is made available under a CC-BY 4.0 International license .

88 whose transmission rates are both equally affected by NPIs, as determined by the

89 parameter $r(0 \leq r \leq 1)$. We assume that, for each strain, the baseline transmission rate is

$90 \beta_{i}(i \in\{w, v\})$, the infection fatality rate (IFR) for single infections is $\alpha_{i}$ (i.e. a proportion $\alpha_{i}$

91 of individuals die from infection, on average), and the average infectious period is $1 / \gamma$.

92 Following a primary infection, an individual is assumed to be fully immune to the strain by

93 which they were infected, and to have acquired partial cross-immunity, $c$, to the other

94 strain $(0 \leq c \leq 1)$. Thus, when $c=0$ there is no cross-immunity between strains and when

$95 c=1$ there is full cross-immunity. Immunity is assumed to act to reduce a host's

96 susceptibility to reinfection [20]. We assume that the variant differs from the wildtype at a

97 single genetic locus, and that mutations occur between strains at rate $\xi$, leading to

98 coinfections by both strains. The IFR for coinfections is assumed to be the average of the

99 wildtype and variant, $\alpha_{C}=\frac{1}{2}\left(\alpha_{w}+\alpha_{v}\right)$.

100

101 At time, $t$, we use the following notation: $S_{t}$ is the number of hosts that are susceptible to both the wildtype and the variant (initially all individuals are susceptible to both strains), $I_{t}^{i}$

103 is the number of primary infections by strain $i, I_{t}^{i j}$ is the number of secondary infections by

104 strain $j$ following recovery from primary infection by strain $i, C_{t}$ is the number of

105 coinfections, $R_{t}^{i}$ is the number of individuals who have recovered from a primary infection

106 by strain $i$ (and are immune to strain $i$ ), and $R_{t}$ the number of individuals who have

107 recovered from both strains (and are therefore immune to both strains). In the absence of

$108 \mathrm{NPIs}$, the per-capita force of infection on fully susceptible hosts for strain $i$ is denoted $\lambda_{t}^{i}=$

$109 \beta_{i}\left(I_{t}^{i}+I_{t}^{j i}+C_{t}\right)(i \neq j$ throughout $)$. We assume that NPIs are triggered (and remain in 
medRxiv preprint doi: https://doi.org/10.1101/2021.05.27.21257938; this version posted May 28, 2021. The copyright holder for this preprint (which was not certified by peer review) is the author/funder, who has granted medRxiv a license to display the preprint in perpetuity.

It is made available under a CC-BY 4.0 International license .

$\left.111 I_{t}^{v w}+C_{t}\right) / N$, first exceeds a threshold of $\epsilon$. Primary infections by strain $i$ therefore occur at

112 per-capita rate $\lambda_{t}^{i}$ before NPIs are triggered and $\lambda_{t}^{i}(1-r)$ after NPIs are triggered. Similarly,

113 secondary infections and coinfections (not arising from mutation) occur at per-capita rates

$114 \lambda_{t}^{i}(1-c)$ and $\lambda_{t}^{i}(1-r)(1-c)$ before and after NPIs are triggered, respectively. The

115 effective (or time-varying) reproduction number [21,22] of strain $i$ at time $t$ in the absence

116 of restrictions, $\mathcal{R}_{t}^{i}$, is therefore:

$$
\mathcal{R}_{t}^{i}=\frac{\beta_{i}}{\gamma}\left(S_{t}+\left(I_{t}^{j}+R_{t}^{j}\right)(1-c)\right)
$$

120 We run simulations of the model using the direct method version of the Gillespie stochastic

121 simulation algorithm [23] using a population size of $N=100,000$ and initial condition

$122\left\{S_{0}, I_{0}^{w}, I_{0}^{v}\right\}=\{N-100,100,0\}$, with 1,000 simulations per parameter set. Since here we

123 are only interested in the emergence of a new variant, we fix the following parameters as

124 they do not qualitatively change our results: $\alpha_{w}=0.005, \xi=5 \times 10^{-5}, \gamma=1 / 5, \beta_{w}=$

$125 \mathcal{R}_{0}^{w} \gamma / N$, and $\mathcal{R}_{0}^{w} \approx 3$. We choose $\beta_{v}$ such that the variant is less $\left(\frac{\beta_{v}}{\beta_{w}}<1\right)$, equally

$126\left(\frac{\beta_{v}}{\beta_{w}}=1\right)$, or more $\left(\frac{\beta_{v}}{\beta_{w}}>1\right)$ transmissible than the wildtype. We also vary the threshold for

127 triggering NPIs $(\epsilon \in\{0,0.2\})$, the level of cross-immunity between the wildtype and variant

$128(0 \leq c \leq 1)$, the strength of NPIs $(0 \leq r \leq 1)$, and the relative IFR of the variant

$129\left(\frac{\alpha_{v}}{\alpha_{w}} \in\{1,2,3\}\right)$. We define emergence by concluding that the variant has emerged if the

130 frequency of infections caused by the variant exceeds $10 \%$ at any time during a simulation.

131 Simulations are terminated when the number of hosts infected reaches 0. 
medRxiv preprint doi: https://doi.org/10.1101/2021.05.27.21257938; this version posted May 28, 2021. The copyright holder for this preprint (which was not certified by peer review) is the author/funder, who has granted medRxiv a license to display the preprint in perpetuity.

It is made available under a CC-BY 4.0 International license .

(a)

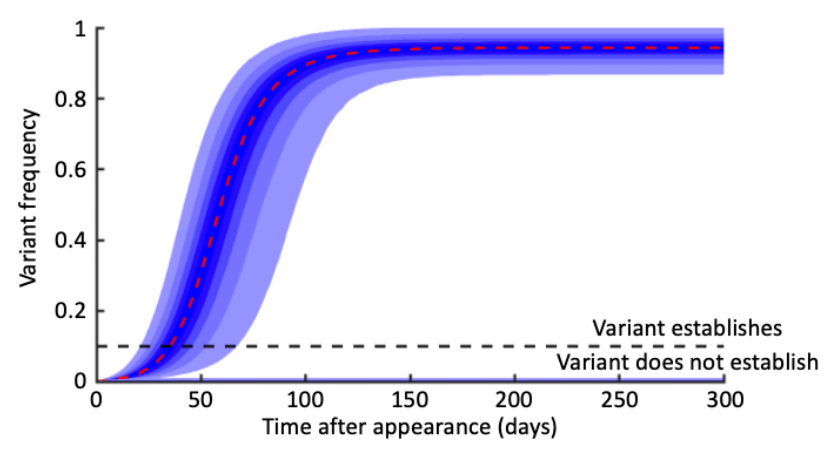

(b)

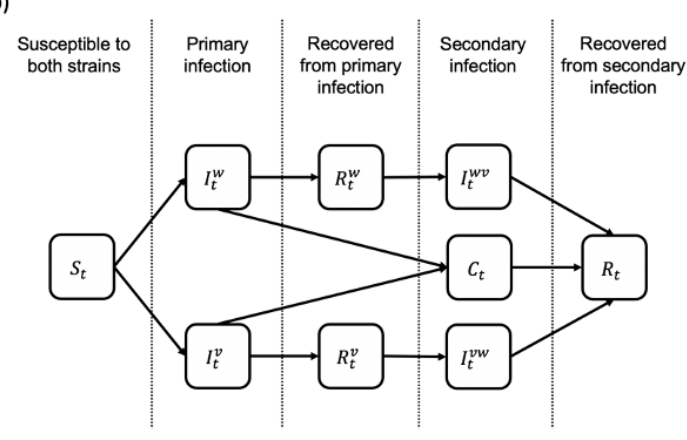

133 Figure 1 - Schematics demonstrating the phenomenon of novel variant establishment and

134 the model used to explore the factors underlying novel variant emergence (appearance

135 followed by establishment). (a) Establishment. Following appearance in the population, the

136 variant may either establish and spread around the population or fail to establish (either

137 because it is less fit than the wildtype or due to stochastic extinction, shown by the thin blue

138 line along the x-axis). (b) Model schematic. Arrows show transitions between classes, as

139 described in the main text. 
medRxiv preprint doi: https://doi.org/10.1101/2021.05.27.21257938; this version posted May 28, 2021. The copyright holder for this preprint (which was not certified by peer review) is the author/funder, who has granted medRxiv a license to display the preprint in perpetuity.

\section{RESULTS}

142 We consider a scenario in which the variant is initially rare relative to the wildtype. The

143 variant is fitter than the wildtype when $\mathcal{R}_{t}^{v}>\mathcal{R}_{t}^{w}$, which requires:

$$
\begin{aligned}
\frac{\mathcal{R}_{t}^{v}}{\mathcal{R}_{t}^{w}} & =\frac{\beta_{v}\left(S_{t}+\left(I_{t}^{w}+R_{t}^{w}\right)(1-c)\right)}{\beta_{w}\left(S_{t}+\left(I_{t}^{v}+R_{t}^{v}\right)(1-c)\right)} \\
& \approx \frac{\beta_{v}}{\beta_{w}}\left(1+\frac{\left(I_{t}^{w}+R_{t}^{w}\right)(1-c)}{S_{t}}\right)>1
\end{aligned}
$$

Hence, a variant is always fitter when it is at least as transmissible as the wildtype and there is not full cross immunity $(c<1)$. However, a less transmissible variant may also be fitter provided the wildtype has already infected a sufficient proportion of the population and there is not full cross immunity. Clearly, when $c<1$ the fitness of the variant will increase relative to the wildtype as the pool of susceptible hosts for the latter is depleted. Note that NPIs do not affect whether a variant is fitter than the wildtype since there is no differential effect on transmission. NPIs will, however, affect mutation supply (and hence the appearance of the variant) and the rate at which the variant can spread (establishment).

158 We initially consider the case when NPIs are triggered immediately ( $\epsilon=0$; Fig. 2) and are

159 sufficiently strong to prevent the wildtype from initially spreading $\left(r>1-\frac{1}{\mathcal{R}_{0}^{w}}\right)$. Unless the mutation rate is very high, it is unlikely that the variant will appear before the wildtype is

161 driven extinct. Thus, the probability of a variant emerging is close to 0 whenever $r>1-\frac{1}{\mathcal{R}_{0}^{w}}$ 
medRxiv preprint doi: https://doi.org/10.1101/2021.05.27.21257938; this version posted May 28, 2021. The copyright holder for this preprint (which was not certified by peer review) is the author/funder, who has granted medRxiv a license to display the preprint in perpetuity.

It is made available under a CC-BY 4.0 International license .

162 regardless of transmissibility or cross immunity (Fig. 2g-i). When $r<\min \left\{1-\frac{1}{\mathcal{R}_{0}^{w}}, 1-\frac{1}{R_{t}^{v}}\right\}$,

163 the probability of a variant emerging depends on the relative transmissibility of the variant,

164 the strength of cross immunity, and the strength of NPIs. When cross immunity and NPIs are

165 both relatively weak, there is a high probability of variants emerging (Fig. $2 \mathrm{~g}$-i). This is

166 because there is a high mutation supply (weak restrictions) to generate the variant and a

167 large pool of susceptible individuals to exploit.

168

169 When the variant is less or equally as transmissible as the wildtype, there is an inverse effect

170 of cross immunity and NPIs on the probability of the variant emerging: weaker NPIs require

171 stronger cross immunity, and vice versa, to prevent the variant emerging (Fig. 2g-h). When

172 the variant is sufficiently more transmissible, however, it has a high probability of emerging

173 even when cross immunity is strong (Fig. 2i). Most notably, the variant is more likely to

174 emerge for intermediate NPIs when cross-immunity is very high or complete $(c \approx 1)$. This is

175 because when NPIs are weak $(r \ll 1)$, there is a large outbreak of the wildtype, which leads

176 to a high mutation supply but also rapidly depletes the pool of hosts for the variant due to

177 cross-immunity (Fig. 3a, d). Thus, while a variant is likely to appear, it is unlikely to spread

178 widely in the population due to herd immunity [24]. When NPIs are stronger (but not too

179 strong) the wildtype causes a smaller outbreak, leading to a lower build-up of cross

180 immunity in the population while still maintaining a sufficient mutation supply for the

181 variant to appear with high probability (Fig. 3b, e). This creates just the right conditions to

182 allow the variant to sweep into the population. As a result of this phenomenon, it is possible

183 for total deaths (for both strains) to peak at intermediate NPIs when the variant is both

184 more transmissible and more deadly than the wildtype (Fig. 4). 

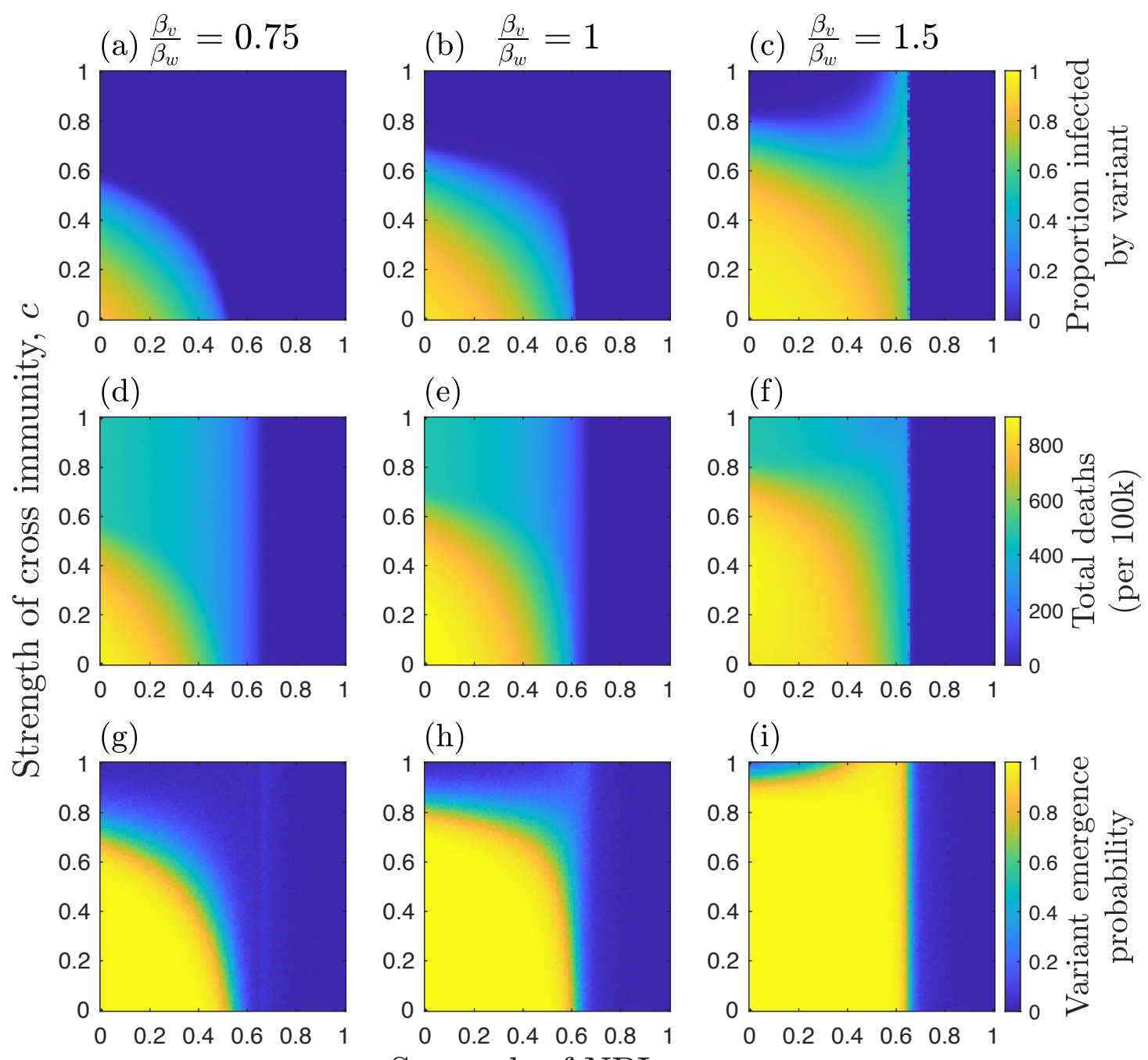

(e)
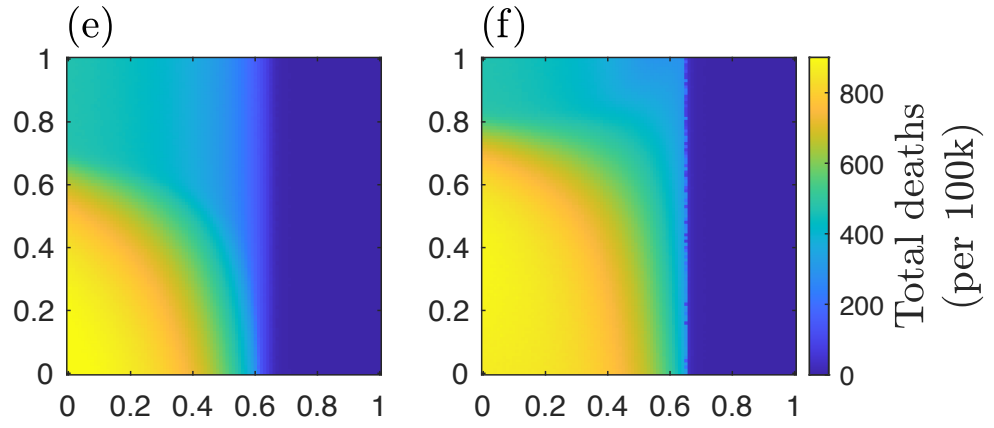

(h)

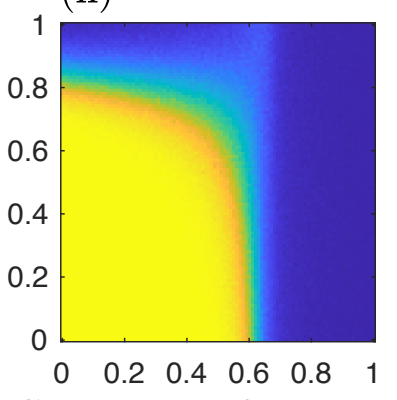

(i)

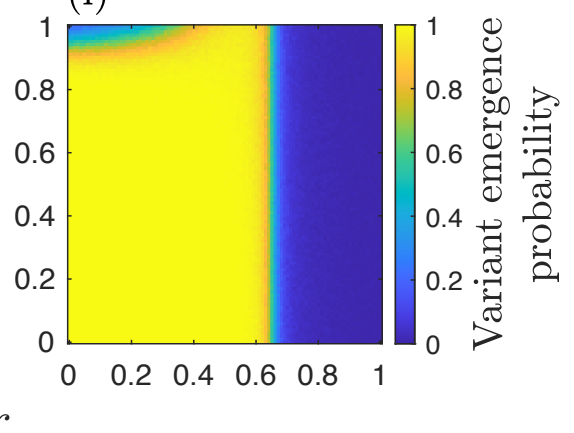

186 Figure 2 - Effects of the strength of NPIs $(r)$, strength of cross immunity $(c)$, and relative

187 transmissibility of the variant $\left(\beta_{v} / \beta_{w}\right.$; as indicated at the top of each column) on: (a)-(c)

188 median proportion of hosts infected by the variant; (d)-(f) median total deaths (per 100k)

189 for both strains; and (g)-(i) the probability of the variant emerging (reaching a frequency of

190 at least 0.1). Data are shown for 100 simulations of each parameter combination. The NPI

191 trigger threshold is $\epsilon=0$ (i.e. NPIs are triggered at the start of each simulation). Other 


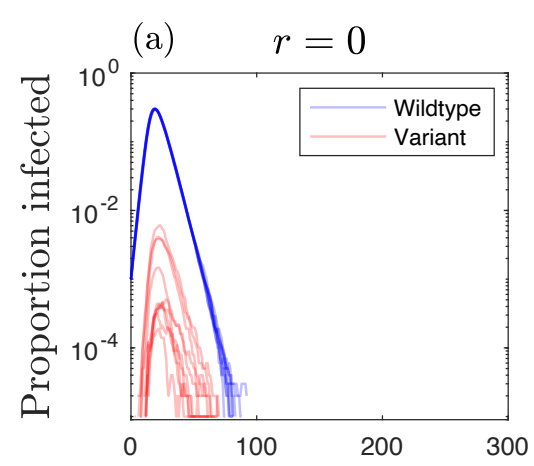

(d)

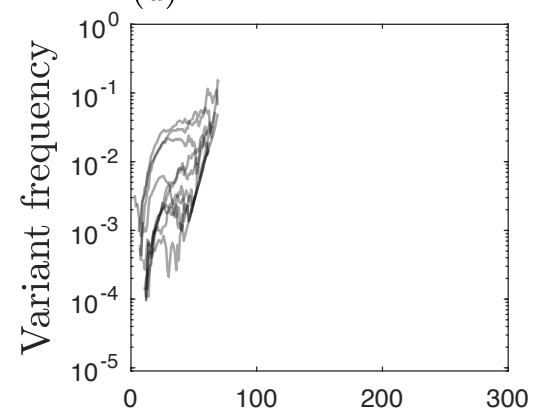

193

194 Figure 3 - Simulations with full cross immunity and a more transmissible variant $\left(\frac{\beta_{v}}{\beta_{w}}=1.5\right)$

195 for different levels of NPIs: (a, d) no NPIs $(r=0)$; (b, e) intermediate NPIs $(r=0.5)$; (c, f)

196 strong NPIs $(r=0.75)$. (a-c) Proportion infected by the wildtype (blue) and by the variant

197 (red). (d-f) Frequency of the variant. Simulations were terminated when the pathogen was
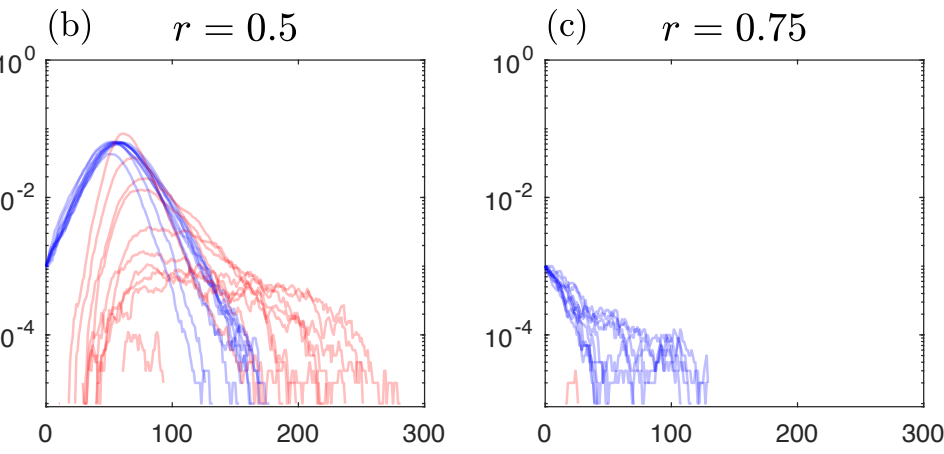

(e)
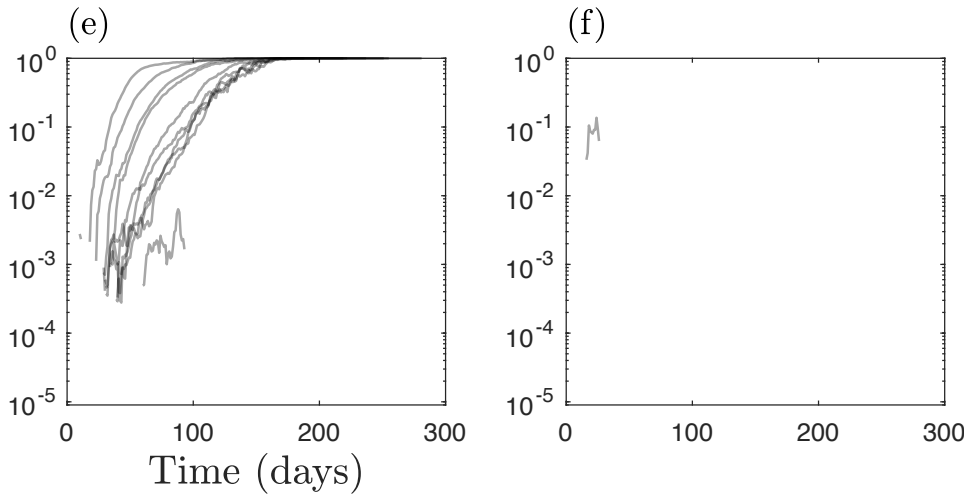
medRxiv preprint doi: https://doi.org/10.1101/2021.05.27.21257938; this version posted May 28, 2021. The copyright holder for this preprint (which was not certified by peer review) is the author/funder, who has granted medRxiv a license to display the preprint in perpetuity.

It is made available under a CC-BY 4.0 International license .

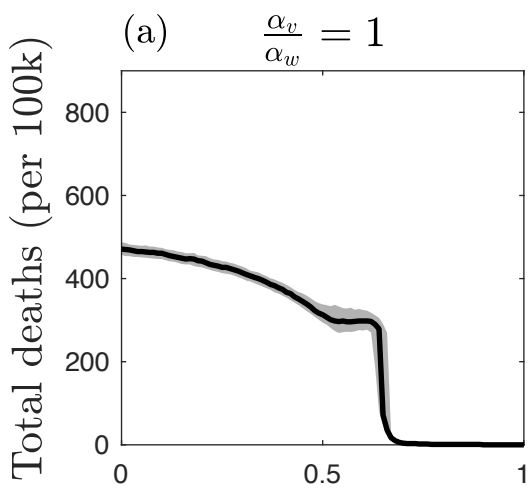

199

200 Figure 4 - Effects of NPIs $(r)$ and the relative virulence (IFR) $\left(\alpha_{v} / \alpha_{w}\right)$ of a more

201 transmissible variant $\left(\beta_{v} / \beta_{w}=1.5\right)$ on total deaths (per 100k) when there is full cross

202 immunity $(c=1)$ and NPIs are timely $(\epsilon=0)$. Plots show the median (black) along with the upper and lower quartiles (grey) over 100 simulations. Other parameters as described in the
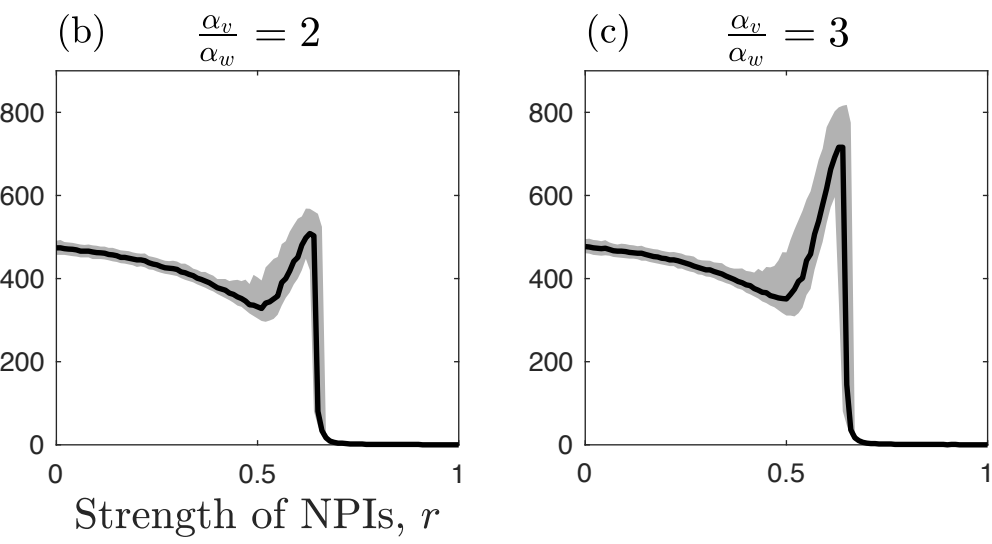
main text. 
medRxiv preprint doi: https://doi.org/10.1101/2021.05.27.21257938; this version posted May 28, 2021. The copyright holder for this preprint (which was not certified by peer review) is the author/funder, who has granted medRxiv a license to display the preprint in perpetuity.

It is made available under a CC-BY 4.0 International license.

206 We now consider the case where NPIs are delayed until $20 \%$ of the population is infected

207 (Fig. 5). There are three notable effects of delaying NPIs. First, since NPIs are delayed, a non-

208 negligible number of deaths now occur over the full range of NPI strengths (Fig. 5d-f).

209 Second, as the initial mutation supply is no longer curtailed by NPIs, variants can emerge

210 during the early stages for $r>1-\frac{1}{R_{0}^{w}}$ (Fig. 5i). Third, more transmissible variants which

211 experience sufficiently high cross immunity with the wildtype $(c \approx 1)$ are no longer likely to

212 emerge at intermediate NPIs (compare Fig. 2i and Fig. 5i). This is because cross immunity

213 accumulates in the population to prevent the more transmissible variant from establishing.

214 Consequently, there is no effect of varying the relative mortality on total deaths when NPIs

215 are delayed for a more transmissible variant with high cross immunity (Fig. S1). 


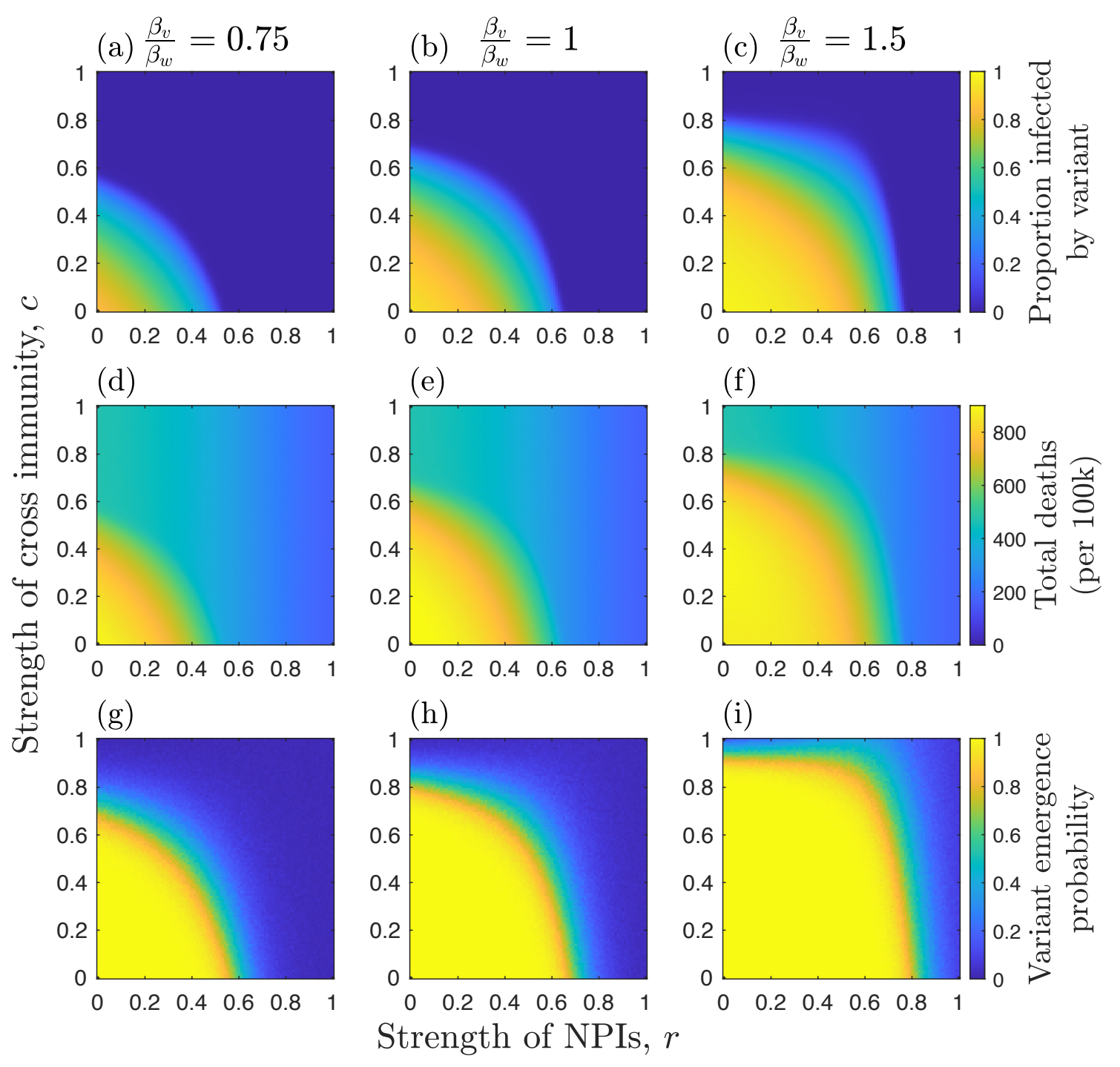

217 Figure 5 - Effects of the strength of NPIs $(r)$, strength of cross immunity $(c)$, and relative

218 transmissibility of the variant $\left(\beta_{v} / \beta_{w}\right)$; as indicated at the top of each column) on: (a)-(c)

219 median proportion of hosts infected by the variant; (d)-(f) median total deaths (per 100k)

220 for both strains; and (g)-(i) the probability of the variant emerging (reaching a frequency of

221 at least 0.1). Data are shown for 100 simulations of each parameter combination. The NPI

222 trigger threshold is $\epsilon=0.2$ (i.e. NPIs are triggered when $20 \%$ of the host population is

223 infected by either strain). Other parameters as described in the main text, with: $\alpha_{v} / \alpha_{w}=1$. 
medRxiv preprint doi: https://doi.org/10.1101/2021.05.27.21257938; this version posted May 28, 2021. The copyright holder for this preprint (which was not certified by peer review) is the author/funder, who has granted medRxiv a license to display the preprint in perpetuity.

It is made available under a CC-BY 4.0 International license .

\section{Discussion}

225 The emergence of novel variants depends on the interaction between mutation supply and

226 the strength of selection, both of which are influenced by NPIs. Here, we have shown how

227 NPIs and the stage of an epidemic at which they are triggered affect the emergence of novel

228 variants with a range of life-history characteristics. Although stronger, earlier

229 implementation of NPIs generally reduces the likelihood that a novel variant will emerge,

230 more transmissible variants that exhibit a high degree of cross immunity with the wildtype may be most likely to emerge when NPIs are enacted early but are of insufficient strength to drive the wildtype extinct quickly (Fig. 2i, Fig. 3b). This echoes a theoretical result for vaccination, which suggests that imperfect vaccination may provide the optimal conditions for vaccine-escape variants to emerge $[8,25]$. This is because imperfect vaccination can allow a significant mutation supply while also exerting selective pressure for vaccine-escape variants. wildtype can occur. This allows a variant to appear (high mutation supply) but prevents it from spreading widely due to the accumulation of cross immunity in the host population

241 (the variant cannot establish). When NPIs are at an intermediate level, however, there may be sufficient mutation supply to allow the variant to appear but insufficient accumulation of cross immunity from the wildtype. The higher transmissibility of the variant then facilitates

244 its establishment. If the variant is also sufficiently more virulent, then it is possible that this

245 will increase the overall number of deaths (Fig. 4). These patterns at high cross immunity disappear when NPIs are delayed, but in general the variant is able to emerge over a wider set of conditions compared to when NPIs are introduced quickly. 
medRxiv preprint doi: https://doi.org/10.1101/2021.05.27.21257938; this version posted May 28, 2021. The copyright holder for this preprint (which was not certified by peer review) is the author/funder, who has granted medRxiv a license to display the preprint in perpetuity.

It is made available under a CC-BY 4.0 International license .

249 While it is possible that intermediate strength or timely NPIs may occasionally lead to more negative outcomes than weaker or delayed NPIs as described above, we note that this requires the variant to have a specific set of characteristics. Since it is challenging to predict the phenotypic characteristics of novel variants, we contend that the optimal strategy to prevent variants of concern arising is almost always to ensure that NPIs are strong and implemented in a timely fashion. If this is done, then the mutation supply is constrained, preventing novel variants from appearing in the first place.

257 Of course, when deciding to implement strong and timely NPIs, a range of factors must be accounted for. The possibility that the wildtype might fade out without invading the host population in the absence of NPIs could be considered $[26,27]$. In that case, it may be unnecessary to introduce costly NPIs [28]. On the other hand, it may be impossible to contain or eradicate a pathogen, even if strong NPIs are introduced [5]. In that scenario, potential negative non-disease health outcomes of NPIs should be considered, particularly if NPIs are maintained over long periods. Comparing the costs and benefits of a range of public health measures is an essential area of research $[29,30]$. As we have demonstrated, potential evolutionary consequences of different NPIs could be an important component of such analyses. made several simplifying assumptions in our modelling approach. First, we assumed that there is no differential effect of NPIs on the wildtype and the variant transmission rates.

271 While this is often likely to be true, it is possible that NPIs may affect some variants more 
medRxiv preprint doi: https://doi.org/10.1101/2021.05.27.21257938; this version posted May 28, 2021. The copyright holder for this preprint (which was not certified by peer review) is the author/funder, who has granted medRxiv a license to display the preprint in perpetuity.

It is made available under a CC-BY 4.0 International license .

272 than others. For example, if symptomatic people are more likely to be identified and

273 isolated, then selection may favour variants that cause more asymptomatic infections or

274 that have a longer incubation period. Similarly, if individuals are isolated following contact

275 tracing, then variants with shorter generation times may be favoured. Second, our model

276 does not include population heterogeneity or contact structure, both of which affect

277 pathogen transmission and the emergence of variants. If, for example, some individuals are

278 less likely to adhere to NPIs, then it may be easier for new variants to emerge. This effect

279 may be particularly pronounced if those individuals belong to specific groups in a population

280 within which transmission may occur. Third, for simplicity we assumed that the wildtype

281 and variant only differed by one mutation at a single genetic locus with potential pleiotropic

282 effects on antigenicity, transmissibility, and virulence. In reality, genetic and phenotypic

283 landscapes are complex, with multiple mutations sometimes required to transition between

284 variants, some of which may be initially neutral or deleterious due to epistasis. For example,

285 the B.1.1.7 SARS-CoV-2 variant that emerged in the United Kingdom in late 2020, and the

286 B.1.351 variant that emerged in South Africa, were found to have unusually large numbers

287 of genetic changes, particularly in the spike protein [31,32]. Finally, we did not model the

288 effects of vaccination programmes on the potential for new variants to emerge, as these

289 have been considered elsewhere [8-11,33].

290

291 Despite these simplifications to our model, our results allowed us to demonstrate important

292 principles about the effects of NPIs on the emergence on variants and are likely to be

293 qualitatively robust with respect to the effects of NPIs. For instance, some differential

294 effects of NPIs are simply equivalent to altering the transmissibility of the variant.

295 Population heterogeneity and contact structure both affect pathogen transmission, and so 
medRxiv preprint doi: https://doi.org/10.1101/2021.05.27.21257938; this version posted May 28, 2021. The copyright holder for this preprint (which was not certified by peer review) is the author/funder, who has granted medRxiv a license to display the preprint in perpetuity.

It is made available under a CC-BY 4.0 International license .

are also likely to affect the initial spread of variants. We would therefore expect the emergence probability to increase in some cases and decrease in others. However, the qualitative patterns shown here are unlikely to change. Finally, increasing the genetic and phenotypic landscape will tend to make it more difficult for variants to emerge. This is because a greater number of mutations, some of which may be deleterious due to epistasis, are likely to be required to generate the variant. One could crudely model this by reducing the mutation supply in our model to mimic the lower rate of accumulating multiple mutations, which would quantitatively, but not qualitatively, change our results.

In conclusion, NPIs have significant impacts on the emergence of novel variants by mediating both the mutation supply and the strength of selection. Although stronger NPIs generally reduce the probability that a new variant of concern will emerge, there are circumstances - namely, when cross immunity is high and the variant is more transmissible - where NPIs of intermediate strength can increase variant emergence, potentially leading to a higher level of mortality. However, this requires a very particular set of circumstances and one cannot predict where a variant will emerge in phenotype space (i.e. its transmissibility, virulence, and level of cross immunity). The optimal strategy to prevent variants emerging is therefore to ensure that NPIs are sufficiently strong to drive the wildtype extinct, thereby cutting off the mutation supply.

\section{AUTHOR CONTRIBUTIONS}

317 BA conceived the study and carried out the modelling work. BA and RNT wrote the manuscript. 
medRxiv preprint doi: https://doi.org/10.1101/2021.05.27.21257938; this version posted May 28, 2021. The copyright holder for this preprint (which was not certified by peer review) is the author/funder, who has granted medRxiv a license to display the preprint in perpetuity.

It is made available under a CC-BY 4.0 International license .

321 Source code for the simulations is available in the online Supplementary Materials and at

322 https://github.com/ecoevogroup/Ashby_Thompson_2021.

323

324 ACKNOWLEDGEMENTS

325 BA is supported by the Natural Environment Research Council (grant numbers

NE/N014979/1 and NE/V003909/1).

327

\section{REFERENCES}

329 1. Day T, Gandon S, Lion S, Otto SP. On the evolutionary epidemiology of SARS-CoV-2.

$330 \quad$ Curr Biol. 2020;30.

331 2. Porco TC, Lloyd-Smith JO, Gross KL, Galvani AP. The effect of treatment on pathogen virulence. J Theor Biol. 2005;233.

3. Read AF, Baigent SJ, Powers C, Kgosana LB, Blackwell L, Smith LP, et al. Imperfect vaccination can enhance the transmission of highly virulent pathogens. PLoS Biol. $2015 ; 13$.

4. Liu Y, Morgenstern C, Kelly J, Lowe R, Jit M. The impact of non-pharmaceutical interventions on SARS-CoV-2 transmission across 130 countries and territories. BMC Med. 2021;19: 40.

5. Thompson RN, Hollingsworth TD, Isham V, Arribas-Bel D, Ashby B, Britton T, et al. Key questions for modelling COVID-19 exit strategies. Proc R Soc B Biol Sci. 2020;287: 20201405.

342 6. Li Y, Campbell H, Kulkarni D, Harpur A, Nundy M, Wang X, et al. The temporal 
medRxiv preprint doi: https://doi.org/10.1101/2021.05.27.21257938; this version posted May 28, 2021. The copyright holder for this preprint (which was not certified by peer review) is the author/funder, who has granted medRxiv a license to display the preprint in perpetuity.

It is made available under a CC-BY 4.0 International license .

association of introducing and lifting non-pharmaceutical interventions with the time-

varying reproduction number (R) of SARS-CoV-2: a modelling study across 131 countries. Lancet Infect Dis. 2021;21.

$3467 . \quad$ Moore S, Hill EM, Tildesley MJ, Dyson L, Keeling MJ. Vaccination and nonpharmaceutical interventions for COVID-19: a mathematical modelling study. Lancet Infect Dis. 2021;S1473-3099: 00143-2.

8. Saad-Roy CM, Morris SE, Metcalf CJE, Mina MJ, Baker RE, Farrar J, et al. Epidemiological and evolutionary considerations of SARS-CoV-2 vaccine dosing regimes. Science (80- ). 2021; eabg8663.

352

9. Cobey S, Larremore DB, Grad YH, Lipsitch M. Concerns about SARS-CoV-2 evolution should not hold back efforts to expand vaccination. Nat Rev Immunol. 2021;21: 330335. Available: https://nrs.harvard.edu/URN-3:HUL.INSTREPOS:37366988

10. Thompson RN, Hill EM, Gog JR. SARS-CoV-2 incidence and vaccine escape. Lancet Infect Dis. 2021;S1473-3099: 00202-4.

11. Gog JR, Hill EM, Danon L, Thompson RN. Vaccine escape in heterogeneous populations: insights for SARS-CoV-2 from a simple model. medRxiv. 2021.

12. Sah P, Vilches TN, Moghadas SM, Fitzpatrick MC, Singer BH, Hotez PJ, et al. Accelerated vaccine rollout is imperative to mitigate highly transmissible COVID-19 variants. EClinicalMedicine. 2021;35: 100865.

13. Bieniasz PD. The case against delaying Severe Acute Respiratory Syndrome Coronavirus 2 (SARS-CoV-2) mRNA vaccine boosting doses. Clin Infect Dis. 2021; ciab070.

14. Gurevich Y, Ram Y, Hadany L. Modeling the evolution of SARS-CoV-2 under nonpharmaceutical interventions. medRxiv. 2021. 
medRxiv preprint doi: https://doi.org/10.1101/2021.05.27.21257938; this version posted May 28, 2021. The copyright holder for this preprint (which was not certified by peer review) is the author/funder, who has granted medRxiv a license to display the preprint in perpetuity.

It is made available under a CC-BY 4.0 International license .

367

15. van Dorp L, Richard D, Tan CCS, Shaw LP, Acman M, Balloux F. No evidence for increased transmissibility from recurrent mutations in SARS-CoV-2. Nat Commun. 2020;11: 5986.

16. Kucharski A, Gog JR. Influenza emergence in the face of evolutionary constraints. Proc R Soc B Biol Sci. 2012;279: 645-652.

17. Abu-Raddad $\amalg$, Ferguson NM. The impact of cross-immunity, mutation and stochastic extinction on pathogen diversity. Proc R Soc B Biol Sci. 2004;271: 2431-2438.

18. Gog JR. The impact of evolutionary constraints on influenza dynamics. Vaccine. 2008;26S: C15-C24.

19. Ferguson NM, Galvani AP. The impact of antigenic variation on pathogen population structure, fitness and dynamics. In: Craig A, Scherf A, editors. Antigenic Variation. 2003. pp. 403-432.

20. Thompson RN, Thompson CP, Pelerman O, Gupta S, Obolski U. Increased frequency of travel in the presence of cross-immunity may act to decrease the chance of a global pandemic. Philos Trans R Soc B. 2019;374: 20180274.

21. Cori A, Ferguson NM, Fraser C, Cauchemez S. A new framework and software to estimate time-varying reproduction numbers during epidemics. Am J Epidemiol. 2013;178: 1505-12.

22. Thompson RN, Stockwin JE, van Gaalen RD, Polonsky JA, Kamvar ZN, Demarsh PA, et al. Improved inference of time-varying reproduction numbers during infectious disease outbreaks. Epidemics. 2019;29.

23. Gillespie DT. Exact stochastic simulation of coupled chemical reactions. J Phys Chem. 1977;8: 2340-2361.

24. Ashby B, Best A. Herd immunity. Curr Biol. 2021;31: R174-R177. 
medRxiv preprint doi: https://doi.org/10.1101/2021.05.27.21257938; this version posted May 28, 2021. The copyright holder for this preprint (which was not certified by peer review) is the author/funder, who has granted medRxiv a license to display the preprint in perpetuity.

It is made available under a CC-BY 4.0 International license .

391

393

394

395

396

398

399

400

401

402

403

404

405

406

407

408

409

410

411

412

413

25. Grenfell BT, Pybus OG, Gog JR, Wood JLN, Daly JM, Mumford JA, et al. Unifying the epidemiological and evolutionary dynamics of pathogens. Science (80- ). 2004;303: 327-333.

26. Gandon S, Hochberg ME, Holt RD, Day T. What limits the evolutionary emergence of pathogens? Philos Trans R Soc B Biol Sci. 2013;368: 20120086.

27. Chabas H, Lion S, Nicot A, Meaden S, van Houte S, Moineau S, et al. Evolutionary emergence of infectious diseases in heterogeneous host populations. PLoS Biol. 2018;16: e2006738.

28. Thompson RN, Gilligan CA, Cunniffe NJ. Control fast or control smart: When should invading pathogens be controlled? PLoS Comput Biol. 2018;14: e1006014.

29. Sandmann FG, Davies NG, Vassall A, Edmunds WJ, Jit M, CMMID COVID-19 working group. The potential health and economic value of SARS-CoV-2 vaccination alongside physical distancing in the UK: a transmission model-based future scenario analysis and economic evaluation. Lancet Infect Dis. 2021;S1473-3099: 00079-7.

30. Newbold SC, Finnoff D, Thunström L, Ashworth M, Shogren JF. Effects of physical distancing to control COVID-19 on public health, the economy, and the environment. Environ Resour Econ. 2020;76.

31. Volz E, Mishra S, Chand M, Barrett JC, Johnson R, Geidelberg L, et al. Assessing transmissibility of SARS-CoV-2 lineage B.1.1.7 in England. Nature. 2021;593: 266-269.

32. Tegally H, Wilkinson E, Giovanetti M, Iranzadeh A, Fonseca V, Giandhari J, et al. Detection of a SARS-CoV-2 variant of concern in South Africa. Nature. 2021;592: 438443.

33. Day T, Galvani A, Struchiner C, Gumel A. The evolutionary consequences of vaccination. Vaccine. 2008;26: C1-3. 